\title{
Application of Combination Evaluation Method in Evaluation of Green Agriculture Development Level in China
}

\author{
Duan Lin*, Zhang Ting \\ School of Statistics of Chengdu University of Information Technology, Chengdu, China \\ Email address: \\ Duanlin0816@163.com (Duan Lin),834869336@qq.com (Zhang Ting) \\ ${ }^{*}$ Corresponding author
}

\section{To cite this article:}

Duan Lin, Zhang Ting. Application of Combination Evaluation Method in Evaluation of Green Agriculture Development Level in China. Science Innovation. Vol. 9, No. 2, 2021, pp. 63-71. doi: 10.11648/j.si.20210902.15

Received: March 22, 2021; Accepted: April 20, 2021; Published: April 26, 2021

\begin{abstract}
The first document of the central government in 2021 proposed to strengthen the supervision of agricultural product quality and food safety, and vigorously develop green food and organic food. Green agriculture is the core of the future development of modern agriculture, which is closely related to food safety, environmental protection and sustainable use of resources, and is the basis for realizing agricultural and rural modernization. In this paper, three objective weighting methods (entropy method, principal component analysis method, factor analysis method) were used to assign the weight of China's green agriculture development level index in 2018, and then combined with the combination evaluation method to calculate the comprehensive score and ranking. On this basis, the 31 provinces and cities in China were divided into four types by cluster analysis: high level of green agriculture development, high level of green agriculture development, medium level of green agriculture development and low level of green agriculture development. According to the study, Heilongjiang, Shandong, Jiangsu, Henan and Anhui were the regions with higher green agriculture development in 2018. On the other hand, the five least developed provinces and cities are Beijing, Ningxia, Hainan, Tianjin and Tibet. The overall situation of green agriculture development in China is unbalanced among regions. Therefore, according to the agricultural economic basis of each province or city, some suggestions are put forward in the hope of improving the agricultural production environment, improving the quality of green agricultural products, realizing the balanced development of green agriculture among regions and speeding up the process of agricultural and rural modernization.
\end{abstract}

Keywords: Green Agriculture, Objective Weighting Method, Combination Evaluation Method, Clustering Analysis

\section{组合评价法在中国绿色农业发展水平评价中的应用}

\section{段玲"，张婷}

成都信息工程大学统计学院, 成都, 中国

邮箱

Duanlin0816@163.com（段玲）,834869336@qq.com（张婷）

\begin{abstract}
摘要：2021年中央一号文件提出加强农产品质量和食品安全监管, 大力发展绿色食品、有机食品。绿色农业是今后现 代农业发展的核心，与食品安全、环境保护、资源可持续利用息息相关，是实现农业农村现代化的基础。本文运用三 种客观赋权法（熵值法、主成分分析法、因子分析法）对2018年中国绿色农业发展水平指标权重赋值，再结合组合评 价法计算综合得分及排名。在此基础上运用聚类分析将中国 31 个省市划分为四个类型地区:绿色农业发展高水平地区、 绿色农业发展较高水平地区、绿色农业发展中等水平地区和绿色农业发展低水平地区。研究表明，2018年中国绿色农
\end{abstract}


业发展较高的地区分别是黑龙江、山东、江苏、河南和安徽。反之, 发展水平较为落后的 5 个省市则为北京、宁夏、海 南、天津和西藏。中国绿色农业发展总体状况是地区间发展不均衡, 因此, 结合各省市自身的农业经济基础, 提出几 点建议, 希望能改善农业生产环境, 提高绿色农产品质量, 实现区域间绿色农业均衡发展, 加快农业农村现代化进程。

关键词：绿色农业, 客观赋权法, 组合评价法, 聚类分析

\section{1. 引言}

2021年中央一号文件提出“推进绿色农业发展，实施 保护耕地制度，推进化肥农药减量增效，加强畜禽粪污资 源化利用。加强农产品质量和食品安全监管, 发展绿色农 产品、有机农产品和地理标志农产品。”绿色农业是今后 现代农业发展的核心，与食品安全、环境保护、资源可持 续利用息息相关，是实现农业农村现代化的基础。2006 年, 刘连馥教授在《绿色农业初探》一书中, 明确指出绿 色农业是指充分运用当代的先进科学技术、装备和农业管 理经验, 以促进农产品安全、生态安全、资源安全和提高 农业综合经济效益的协调统一为目标, 以标准化农业生产 为手段, 推动人类社会和经济全面、协调、可持续发展的 农业模式 [1]。严立冬在总结国内绿色农业概念的基础上， 提炼出更为精简的含义, 指出绿色农业是一种有利于环境 保护、有利于农产品数量安全与质量安全的现代农业发展 形态与模式[2]。

纵览近几年文献研究结果发现, 越来越多的专家着重 研究绿色农业指标体系建立和绿色农业发展水平评测的 方法。王保利等针对陕西省渭北绿色产业制定科学的指标 体系, 利用非货币评价方法和层次分析法对绿色产业集群 效益进行评价[3]; 崔元锋等则从生态效益水平指标、经济 效益水平指标、社会效益水平指标等三个方面建立评价指 标子系统, 整理得出中国绿色农业发展水平综合评价体系 [4]; 张正斌等对中国绿色农业的生产环境、生产技术、生 产能力及生产资料方面, 建立绿色农业经济指标、信息化 指标和文化指标等, 对绿色农业基地的建设和评估提供理 论依据[5]; 卢秉福和赵海波对黑龙江省绿色农业发展进行 研究, 运用SWOT方法和层次分析法以及构建绿色供应、 资源节约、环境友好等三个一级指标对黑龙江省绿色农业 发展水平进行评估[6-7]; 田云基于农用物质强度和利用效 率建立绿色发展水平测度指标体系, 再运用主成分分析法 和聚类分析法对中国 31 个地区进行绿色农业发展水平评 估和分类 [8]; 陆壮丽以广西壮族自治区为例, 利用专家评 分法和层次分析法，建立了投入水平、产出水平、信息化 水平、市场发展水平、社会发展水平、农业可持续发展水 平等指标 [9]; 奉梅通过构建四川省绿色农业发展水平评价 指标体系, 采用熵值法和层次分析法计算得到绿色农业发 展水平综合指数, 对绿色农业发展水平进行等级划分[10]。
纵览上述文献可知, 国内学者已从不同视角对绿色 农业展开了深入的研究, 研究结果也具有一定现实指导 意义，但不同的专家对指标体系的建立以及评价方法上 的运用具有差异。除了对指标的选择以外, 还有一个重 点是对指标权重的赋值。我们最常用的主观赋权和客观 赋权方法有: 层次分析法、专家评价法、综合指数法、 熵值法、主成分分析法、因子分析法等。郭显光提出一 种新的指标赋权法一组合评价法, 将几种评价方法进行 组合, 得出更为客观全面的评测结果 [11]。组合评价法在 经济效益评价、投资环境评价、综合经济实力评价方面 都有运用, 基于此, 组合评价法在中国绿色农业发展水 平评价中同样适用。主观赋权法是依据专家经验来评价, 指标数量多, 不同专家对此评价会存在较大差异, 分析 结果趋于不稳定。因此, 本文对我国绿色农业发展水平 将运用三种客观赋值法 (主成分分析法、因子分析法、 熵值法）相结合的组合评价法来对中国 31 个省市的绿色 农业发展水平进行评价。

\section{2. 指标解释与数据来源}

为了全面了解中国省域绿色农业的发展水平, 须建立 具有科学性、综合性、实用性、可操作性的指标体系。这 些指标是通过对绿色农业概念的解析, 综合选出具有代表 性的指标。基于此, 绿色农业发展水平评价指标分为三部 分: 绿色农业资源利用、绿色农业生产环境和绿色农业产 品品牌。分别体现刘连馥老师在绿色农业概念中提出的生 态安全、农产品安全和农业综合经济效益三个方面。其中, 绿色农业生产环境是基础, 绿色农业资源利用是为了促进 农产品安全生产。绿色农业品牌是是绿色农业生产经济效 益的体现, 也是绿色农业发展的目标。结合分析, 分别在 绿色农业资源利用下设置 4 个二级指标, 绿色农业生产环 境 8 个, 绿色农业产业品牌 7 个, 共 19 个二级指标。具体绿 色农业发展水平评价指标如下表 1 ;

文章选取中国31个省市（不包含港澳台地区） 2018 年的数据作为研究对象。数据主要来源于《中国统计年鉴》 和各省市《2018年国民经济和社会发展公报》以及《2018 年绿色食品统计年报》《2018年中国现代农业示范区数量》。

中国现代农业示范区又分为整省创建、整市、区创建、 整县创建三种不同的现代农业示范区, 该文章数据是三种 现代农业示范区数量的总和。

表1 绿色农业发展水平评价指标。

\begin{tabular}{lllll}
\hline 一级指标 & 序号 & 二级指标 & 单位 & 属性 \\
\hline & $\mathrm{X} 1$ & 农药使用量 & 万吨 & 负向 \\
绿色农业资源利用 & $\mathrm{X} 2$ & 农用化肥施用折纯量 & 万吨 & 负向 \\
& $\mathrm{X} 3$ & 农用机械总动力 & 万千瓦 & 正向 \\
& $\mathrm{X} 4$ & 农用塑料薄膜使用量 & 吨 & 负向 \\
\hline
\end{tabular}




\begin{tabular}{|c|c|c|c|c|}
\hline 一级指标 & 序号 & 二级指标 & 单位 & 属性 \\
\hline \multirow{8}{*}{ 绿色农业生产环境 } & $\mathrm{X} 5$ & 森林覆盖率 & $\%$ & 正向 \\
\hline & X6 & 水土流失治理面积 & 千公顷 & 正向 \\
\hline & $\mathrm{X} 7$ & 耕地灌溉面积 & 千公顷 & 正向 \\
\hline & $\mathrm{X} 8$ & 农作物总播种面积 & 千公顷 & 正向 \\
\hline & X9 & 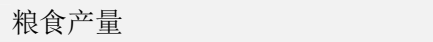 & 万吨 & 正向 \\
\hline & $\mathrm{X} 10$ & 国家现代农业示范区 & 个 & 正向 \\
\hline & X11 & 绿色食品原料标准化生产基地数 & 个 & 正向 \\
\hline & $\mathrm{X} 12$ & 绿色食品原料标准化生产基地产量 & 万吨 & 正向 \\
\hline \multirow{7}{*}{ 绿色农业产品品牌 } & $\mathrm{X} 13$ & 农产品地理标志登记产品总数 & 个 & 正向 \\
\hline & $\mathrm{X} 14$ & 有效用标绿色食品产品数 & 个 & 正向 \\
\hline & $\mathrm{X} 15$ & 有效用标无公害农产品数 & 个 & 正向 \\
\hline & $\mathrm{X} 16$ & 有机食品产品数 & 个 & 正向 \\
\hline & $\mathrm{X} 17$ & 绿色食品生产资料获证企业数 & 个 & 正向 \\
\hline & $\mathrm{X} 18$ & 绿色食品生产资料获证产品数 & 个 & 正向 \\
\hline & X19 & 有效用标绿色食品单位数 & 个 & 正向 \\
\hline
\end{tabular}

\section{3. 研究方法}

\section{1. 主成分分析法权重赋值的基本原理和步骤}

\subsection{1. 主成分分析基本原理}

主成分分析是指将原来具有相关关系的多个指标简 化为少数几个新的综合指标的多元统计方法。

基本原理: 在讨论中国绿色农业发展水平的问题中, 设有 $i$ 个评价对象, $p$ 个指标, 设 $x_{1}, x_{2}, x_{3}, x_{4}, \ldots x_{p}, x_{p}$ 表示 $\mathrm{p}$ 个绿色农业评价指标, 则 $c_{1}, c_{2}, c_{3}, c_{4}, \ldots c_{p}$ 表示各 绿色农业评价指标的权重, 加权之和就是 $y=c_{1} X_{1}+c_{2} x_{2}+\ldots \ldots+c_{P} x_{P}$ 因此, 每个地区都相应得 出一个综合得分, 记为 $y_{1}, y_{2}, y_{3}, y_{4}, \ldots y_{n}, \mathrm{n}$ 表示为第 $\mathrm{n}$ 个主成分。

设 $Y_{i}$ 表示 $\mathrm{i}$ 个主成分, $\mathrm{i}=1,2, \ldots, \mathrm{p}$, 可设

$$
\begin{aligned}
& \mathrm{y}_{1}=c_{11} X_{1}+c_{12} x_{2}+\ldots+c_{1 P} X_{P} \\
& y_{2}=c_{21} x_{1}+c_{22} X_{2}+\ldots \ldots+c_{2 P} X_{P} \\
& y_{P}=c_{P 1} X_{1}+c_{P 2} X_{2}+\ldots+c_{P P} X_{P}
\end{aligned}
$$

其中对每一个 $\mathrm{i}$ 均有 $c_{i 1}{ }^{2}+c_{i 2}{ }^{2}+c_{i p}{ }^{2}=1, y_{1}$ 是第一 主成分, $y_{2}$ 是第二主成分, $y_{p}$ 是第 $p$ 个主成分。

\subsection{2. 主成分分析步骤}

指标数据标准化处理, 对于度量单位不同的指标或是 取值范围彼此差异非常大的指标, 不直接进行主成分分析, 应考虑将数据进行标准化处理, 以消除量纲的影响。

对绿色农业发展水平进行主成分分析的指标变量有 19个: $X_{1}, X_{2}, X_{3} \ldots X_{19}$, 共有 31 个评价对象, 第 $\mathrm{i}$ 个评价对象 的第 $\mathrm{j}$ 指标的取值为 $X_{i j}$, 将各指标值 $X_{i j}$ 转换成标准化指标 $\tilde{X}_{i j}$ 数据标准化公式步骤如下公式:

$$
\tilde{X}_{i j}=\frac{x_{i j}-\tilde{x}_{j}}{S_{j}},(\mathrm{i}=1,2, \ldots, \mathrm{j}=1,2, \ldots)
$$

$$
r_{i j}=\frac{\sum_{k=1}^{n} \tilde{X}_{k i} \cdot \tilde{X}_{k j}}{n-1}(i, \mathrm{j}=1,2, \ldots \mathrm{m})
$$

$$
b_{j}=\frac{\lambda_{j}}{\sum_{k=1}^{m} \lambda_{k}} \mathrm{j}=(1,2, \ldots \mathrm{m})
$$

$$
\alpha_{p}=\frac{\sum_{k=1}^{p} \lambda_{k}}{\sum_{k=1}^{m} \lambda_{k}}
$$

其中即 $\tilde{X}_{j}, S_{j}$ 为第 $\mathrm{j}$ 个指标的样本均值和样本标准差, $R$ 为变量间的相关系数矩阵, $r_{i j}$ 是第 $\mathrm{i}$ 个指标与第 $\mathrm{j}$ 个指标 的相关系数。计算主成分并计算综合得分：计算特征根 $\lambda_{j}(j=1,2, \ldots m), b_{j}$ 为主成分 $y_{1}$ 的信息贡献率, $\alpha_{p}$ 为 主成分 $y_{1}, y_{2} \ldots y_{p}$ 的累计贡献率。

\section{2. 因子分析原理和步骤}

因子分析是对主成分分析的扩展, 是从变量中提取共 性因子的统计。与主成分分析是包含与扩展的关系。通过 
SPSS软件输出结果表 2 可以看出, 对 31 个省市和 19 个统计 指标中提取出 5 个公共因子, 累计贡献率达 $85.69 \%$, 通常 认为累计贡献率达到 $80 \%$ 以上就是较好的因子分析结果。 变量在因子轴旋转之前初始特征值和累计贡献率在因子 分布上是不均衡的, 通过轴旋转使原始变量在公因子上的
载荷重新分布, 旋转后的特征根和贡献率更均衡, 但是总 累计贡献率不变。

指标权重综合得分公式: $\quad \mathrm{y}=0.51263 * \mathrm{y}_{1}+0.1117 * \mathrm{y}_{2}$ $+0.1988 * \mathrm{y}_{3}+0.06599 * \mathrm{y}_{4}+0.05671 * \mathrm{y}_{5}$, 排名结果见表5。

表2 公共因子特征根和累计贡献率。

\begin{tabular}{llllll}
\hline \multirow{2}{*}{ 成份 } & \multicolumn{3}{l}{ 初始特征值 } & & \multicolumn{3}{l}{ 旋转平方和载入 } \\
\cline { 2 - 6 } & 合计 & 方差的\% & 累积 $\%$ & 合计 & 方差的\% \\
\hline 1 & 9.74 & 51.263 & 51.263 & 5.51 & 29.032 \\
2 & 2.12 & 11.170 & 62.433 & 4.23 & 22.263 \\
3 & 2.08 & 10.988 & 73.421 & 3.52 & 18.548 \\
4 & 1.25 & 6.599 & 80.021 & 1.71 & 9.041 \\
5 & 1.07 & 5.671 & 85.692 & 1.29 & 6.809 \\
\hline
\end{tabular}

\section{3. 熵值法指标权重赋值的原理和计算步骤}

\subsection{1. 熵值法赋值指标权重计算公式}

陆添超（2009）研究熵值法在权重确定中的应用时介 绍: “熵”是系统无序程度的度量, 可以用于度量已知数据 所包含的有效信息和确定权重, 在确定指标权重中得到广 泛的应用 [12]。通过对“熵”的计算确定权重, 当计算出某 项评价对象熵值越小, 说明该指标权重越大, 信息量越大。 与之相反, 熵值越大, 指标权重越小, 指标有效信息量少。

通过对中国 31 个省市绿色农业发展水平的指标体系 进行因子分析, 文章设 $\mathrm{m}=56, \mathrm{n}=19, X_{i j}$ 为第 $\mathrm{i}$ 个省市第 $\mathrm{j}$ 项因 子的因子得分, 其中 $\mathrm{i}=1,2, \ldots 31 ; \mathrm{j}=1,2, \ldots, 19$ 。数据无量纲计 算式:

$$
\begin{aligned}
& \text { 正向指标: } x_{i j}^{\prime}=\frac{x_{i j}-\min _{j}}{\max _{j}-\min _{j}} \\
& \text { 负向指标: } x_{i j}=\frac{\max _{j}-x_{i j}}{\max _{j}-\min _{j}}
\end{aligned}
$$

$$
\text { 综合得分计算式: } y=\sum_{i=1}^{m} W_{j} * p_{i j}
$$

\subsection{2. 熵值法计算步骤}

1) 指标数值预处理:

由于每个指标属性不一样, 有些指标是正向指标, 表 示指标数值越大指标表现越好, 有些指标是负向指标 (也 称为逆向指标）表示指标数值越大指标表现越差[13]。如 本文选取的“农用化肥施用折纯量”“农药施用量”和“农用 塑料薄膜施用量”这三个指标均为负向指标。因此，在对 指标数据进行无量纲计算时应注意公式的运用。将其三个 指标进行预处理, 转换为正向指标。

\section{2) 无量纲计算:}

对全部指标数据进行指标无量纲化处理, 消除指标数 值量纲的影响。为了使数据运算处理具有意义, 数值必须 消除零和负值。因此, 无量纲计算后的数据整体向右平移 0.0001 个单位, 其公式为: $X_{i j}=X_{i j}+A, A$ 取值为 0.0001 为了不破坏原始数据的内在规律, $A$ 取值尽可能小且最接 近 $X_{i j}$ 的最小值 $[14]$ 。

3 ) 熵值法赋值计算结果:

依据2018年中国31个省市绿色农业指标数据的无量

\begin{tabular}{|c|c|c|c|c|}
\hline 序号 & 二级指标 & 熵值 & 差异性系数 & 指标权重 \\
\hline $\mathrm{x} 1$ & $\begin{array}{l}\text { 农用化肥施用折纯量 } \\
\end{array}$ & 0.984 & 0.016 & 0.007 \\
\hline $\mathrm{x} 2$ & 农药使用量 & 0.961 & 0.039 & 0.017 \\
\hline $\mathrm{x} 3$ & 农业机械总动力 & 0.893 & 0.107 & 0.048 \\
\hline$x 4$ & 农用塑料薄膜使用量 & 0.976 & 0.024 & 0.011 \\
\hline$x 5$ & 森林覆盖率 & 0.934 & 0.066 & 0.030 \\
\hline$x 6$ & 水土流失治理面积 & 0.907 & 0.093 & 0.042 \\
\hline $\mathrm{x} 7$ & 耕地灌溉面积 & 0.894 & 0.106 & 0.048 \\
\hline $\mathrm{x} 8$ & 农作物总播种面积 & 0.907 & 0.093 & 0.042 \\
\hline x9 & 粮食产量 & 0.877 & 0.123 & 0.056 \\
\hline $\mathrm{x} 10$ & 国家现代农业示范区 & 0.809 & 0.191 & 0.086 \\
\hline $\mathrm{x} 11$ & 绿色食品原料标准化生产基地数 & 0.790 & 0.210 & 0.095 \\
\hline $\mathrm{x} 12$ & 绿色食品原料标准化生产基地产量 & 0.729 & 0.271 & 0.123 \\
\hline $\mathrm{x} 13$ & 有效用标绿色食品单位数 & 0.894 & 0.106 & 0.048 \\
\hline $\mathrm{x} 14$ & 有效用标绿色食品产品数 & 0.890 & 0.110 & 0.050 \\
\hline $\mathrm{x} 15$ & 绿色食品生产资料获证企业数 & 0.853 & 0.147 & 0.066 \\
\hline x16 & 绿色食品生产资料获证产品数 & 0.840 & 0.160 & 0.073 \\
\hline $\mathrm{x} 17$ & 农产品地理标志登记产品总数 & 0.911 & 0.089 & 0.040 \\
\hline $\mathrm{x} 18$ & 有效用标无公害农产品数 & 0.885 & 0.115 & 0.052 \\
\hline $\mathrm{x} 19$ & 有机食品产品数 & 0.860 & 0.140 & 0.063 \\
\hline
\end{tabular}
纲化处理结果, 再计算出各指标的权重, 计算结果见表3。

表3 熵值法赋值计算结果。 
由表3计算结果可以得出，权重大于或等于 $5 \%$ 的指标 中, 生产环境指标有 4 个, 产品品牌指标有 5 个, 累计权重 分别为 $36 \% 、 30.5 \%$, 总计为 $66.5 \%$ 。这表明在绿色农业 发展的构成要素中, 生产环境很重要。另一方面, 绿色农 业资源利用所占权重较少, 说明该项指标数值大小对中国 绿色农业发展水平影响较小。在二级指标的权重中, 绿色 食品原料标准化生产基地数、绿色食品原料标准化生产基 地产量和国家现代农业示范区这三个指标权重所占比例
最高, 说明这三个指标是影响中国绿色农业发展水平的重 要因素。

4）熵值法综合得分及排名:

将上式计算出的绿色农业指标权重 $w_{j}$ 与指标比重 $p_{i j}$ 相乘得出各省市绿色农业发展综合得分, 根据计算结果按 从大到小的顺序进行排名。得分情况及排名见表 4 。

表4 熵值法综合得分及排名。

\begin{tabular}{|c|c|c|c|c|c|}
\hline 省市 & 综合得分 & 排序 & 省市 & 综合得分 & 排序 \\
\hline 北京 & 0.014459 & 26 & 上海 & 0.019407 & 21 \\
\hline 天津 & 0.008313 & 29 & 江苏 & 0.079817 & 3 \\
\hline 河北 & 0.033792 & 11 & 浙江 & 0.031461 & 12 \\
\hline 山西 & 0.014911 & 25 & 安徽 & 0.044542 & 6 \\
\hline 内蒙古 & 0.053406 & 5 & 福建 & 0.024526 & 17 \\
\hline 辽宁 & 0.027303 & 15 & 江西 & 0.030251 & 13 \\
\hline 吉林 & 0.025429 & 16 & 山东 & 0.081072 & 2 \\
\hline 黑龙江 & 0.121846 & 1 & 广东 & 0.024182 & 18 \\
\hline 陕西 & 0.020856 & 20 & 广西 & 0.017812 & 22 \\
\hline 甘肃 & 0.021502 & 19 & 海南 & 0.00529 & 30 \\
\hline 青海 & 0.016129 & 24 & 重庆 & 0.016894 & 23 \\
\hline 宁夏 & 0.010609 & 28 & 四川 & 0.057594 & 4 \\
\hline 新疆 & 0.034262 & 10 & 贵州 & 0.012736 & 27 \\
\hline 河南 & 0.039106 & 8 & 云南 & 0.028007 & 14 \\
\hline 湖北 & 0.037676 & 9 & 西藏 & 0.002857 & 31 \\
\hline 湖南 & 0.043954 & 7 & & & \\
\hline
\end{tabular}

\section{4. 组合评价法在绿色农业发展水平评价中的应用}

\section{1. 三种客观赋权法的评价结果}

为了更好的比较三种客观赋值法在绿色农业发展水平评价中应用，对主成分分析法、因子分析法和熵值法进行进 行综合评价, 其中主成分分析和因子分析法是运用统计分析软件SPSS进行分析计算, 熵值法则是运用EXCEL进行计算。 三种方式综合得分及排名结果见表5。

表5 三种客观赋权法的评价结果。

\begin{tabular}{|c|c|c|c|c|c|c|}
\hline 省市 & 得分 1 & 排名 & 得分2 & 排名 & 得分 3 & 排名 \\
\hline 北京 & -1.65 & 27 & -0.78 & 28 & 0.014 & 26 \\
\hline 天津 & -1.98 & 30 & -0.78 & 29 & 0.008 & 29 \\
\hline 河北 & 0.54 & 10 & 0.69 & 5 & 0.034 & 11 \\
\hline 山西 & -0.96 & 23 & -0.43 & 24 & 0.015 & 25 \\
\hline 内蒙古 & 1.27 & 7 & 0.08 & 14 & 0.053 & 5 \\
\hline 辽宁 & -0.16 & 14 & -0.08 & 17 & 0.027 & 15 \\
\hline 吉林 & -0.19 & 15 & 0.2 & 12 & 0.025 & 16 \\
\hline 黑龙江 & 5.09 & 1 & 0.84 & 3 & 0.122 & 1 \\
\hline 陕西 & -0.77 & 21 & -0.26 & 18 & 0.021 & 20 \\
\hline 甘肃 & -0.43 & 18 & -0.37 & 22 & 0.022 & 19 \\
\hline 青海 & -1.61 & 26 & -0.77 & 27 & 0.016 & 24 \\
\hline 宁夏 & -1.69 & 28 & -0.74 & 26 & 0.011 & 28 \\
\hline 新疆 & 0.12 & 11 & 0.07 & 15 & 0.034 & 10 \\
\hline 河南 & 1.43 & 5 & 1.71 & 1 & 0.039 & 8 \\
\hline 湖北 & 0.88 & 9 & 0.46 & 7 & 0.038 & 9 \\
\hline 湖南 & 1.12 & 8 & 0.66 & 6 & 0.044 & 7 \\
\hline 上海 & -1.58 & 25 & -0.92 & 31 & 0.019 & 21 \\
\hline 江苏 & 2.19 & 3 & 0.28 & 8 & 0.080 & 3 \\
\hline 浙江 & -0.31 & 16 & -0.35 & 20 & 0.031 & 12 \\
\hline 安徽 & 1.29 & 6 & 0.76 & 4 & 0.045 & 6 \\
\hline 福建 & -0.53 & 20 & -0.29 & 19 & 0.025 & 17 \\
\hline
\end{tabular}




\begin{tabular}{lllllll}
\hline 省市 & 得分 & 排名 & 得分2 & 排名 & 得分 3 & 排名 \\
\hline 江西 & 0.05 & 12 & 0.05 & 16 & 0.030 & 2 \\
山东 & 3.44 & 2 & 1.18 & 2 & 0.081 & 13 \\
广东 & -0.42 & 17 & 0.21 & 11 & 0.024 & 18 \\
广西 & -0.51 & 19 & 0.24 & 10 & 0.018 & 22 \\
海南 & -1.85 & 29 & -0.51 & 25 & 0.005 & 30 \\
重庆 & -0.93 & 22 & -0.41 & 23 & 0.017 & 23 \\
四川 & 1.51 & 4 & 0.28 & 9 & 0.058 & 27 \\
贵州 & -1.17 & 24 & -0.36 & 21 & 0.013 & 14 \\
云南 & 0.02 & 13 & 0.14 & 13 & 0.028 & 31 \\
西藏 & -2.22 & 31 & -0.8 & 30 & 0.003 & \\
\hline
\end{tabular}

由表 5 三种综合评价方法计算结果可以看出, 因选用 三种不同的指标赋值法进行评价, 其评价结果也出现了差 异, 但总体排名相差不会太大, 说明三种方法计算结果均 具有合理性。例如北京，在三种方法计算中主成分分析的 综合得分排名在 27 名, 因子分析排名在 28 名, 熵值法排名 26名。三种客观赋值法是从三种不同的角度进行的综合评 价, 都具有合理性。因此, 我们不能轻易舍弃其中任意一 种方式。

\section{2. 三种综合评价结果的组合}

三种客观赋值法在指标赋权中都很重要, 我们将三种 方法进行组合。组合的方法是先将每种方法排序的名次转 化为分数, 如果排序为第 $m$ 名, 则其得分为 $n+1-m$ 分, 即第1名得 $n$ 分......第 $n$ 名得1分, 其中如有相同的名次, 则取这几个位置的平均分, 然后将三种方法的分数进行平 均, 得出组合分数 [15]。计算结果见表 6 。

表6 组合评价法下各省市排名。

\begin{tabular}{|c|c|c|c|c|c|}
\hline 省市 & 方法1分数 & 方法 2 分数 & 方法3分数 & 组合分数 & 组合名次 \\
\hline 北京 & 5.0 & 4.0 & 6.0 & 5.0 & 27 \\
\hline 天津 & 2.0 & 3.0 & 3.0 & 2.7 & 30 \\
\hline 河北 & 22.0 & 27.0 & 21.0 & 23.3 & 10 \\
\hline 山西 & 9.0 & 8.0 & 7.0 & 8.0 & 24 \\
\hline 内蒙古 & 25.0 & 18.0 & 27.0 & 23.3 & 9 \\
\hline 辽宁 & 18.0 & 15.0 & 17.0 & 16.7 & 15 \\
\hline 吉林 & 17.0 & 20.0 & 16.0 & 17.7 & 14 \\
\hline 黑龙江 & 31.0 & 29.0 & 31.0 & 30.3 & 1 \\
\hline 陕西 & 11.0 & 14.0 & 12.0 & 12.3 & 20 \\
\hline 甘肃 & 14.0 & 10.0 & 13.0 & 12.3 & 21 \\
\hline 青海 & 6.0 & 5.0 & 8.0 & 6.3 & 26 \\
\hline 宁夏 & 4.0 & 6.0 & 4.0 & 4.7 & 28 \\
\hline 新疆 & 21.0 & 17.0 & 22.0 & 20.0 & 11 \\
\hline 河南 & 27.0 & 31.0 & 24.0 & 27.3 & 4 \\
\hline 湖北 & 23.0 & 25.0 & 23.0 & 23.7 & 8 \\
\hline 湖南 & 24.0 & 26.0 & 25.0 & 25.0 & 6 \\
\hline 上海 & 7.0 & 1.0 & 11.0 & 6.3 & 25 \\
\hline 江苏 & 29.0 & 24.0 & 29.0 & 27.3 & 3 \\
\hline 浙江 & 16.0 & 12.0 & 20.0 & 16.0 & 17 \\
\hline 安徽 & 26.0 & 28.0 & 26.0 & 26.7 & 5 \\
\hline 福建 & 12.0 & 13.0 & 15.0 & 13.3 & 19 \\
\hline 江西 & 20.0 & 16.0 & 19.0 & 18.3 & 13 \\
\hline 山东 & 30.0 & 30.0 & 30.0 & 30.0 & 2 \\
\hline 广东 & 15.0 & 21.0 & 14.0 & 16.7 & 16 \\
\hline 广西 & 13.0 & 22.0 & 10.0 & 15.0 & 18 \\
\hline 海南 & 3.0 & 7.0 & 2.0 & 4.0 & 29 \\
\hline 重庆 & 10.0 & 9.0 & 9.0 & 9.3 & 22 \\
\hline 四川 & 28.0 & 23.0 & 23.0 & 24.7 & 7 \\
\hline 贵州 & 8.0 & 11.0 & 5.0 & 8.0 & 23 \\
\hline 云南 & 19.0 & 19.0 & 18.0 & 18.7 & 12 \\
\hline 西藏 & 1.0 & 2.0 & 1.0 & 1.3 & 31 \\
\hline
\end{tabular}

由组合评价的最后得分计算结果可以看出, 中国绿色农业发展水平较高的前 5 个省市为黑龙江、山东、江苏、河南 和安徽。反之, 发展水平较为落后的 5 个省市则为北京、宁夏、海南、天津和西藏。 


\section{3. 中国绿色农业发展区域特征和差异分析}

通过组合分析法对中国 31 个省市绿色农业发展水平的高低进行了排序，可以看出各区域的发展存在差异，为了更 好的观察这种区域差异和发展特征，我们将 31 个省市按照中国七大经济区进行划分，来观察区域内各省市发展是否均 衡, 见表7。

表7 七大经济区绿色农业发展排名。

\begin{tabular}{|c|c|c|c|c|c|}
\hline 区域 & 省市 & 排名 & 区域 & 省市 & 排名 \\
\hline \multirow{5}{*}{ 华北地区 } & 北京 & 27 & \multirow{8}{*}{ 华东地区 } & 上海 & 25 \\
\hline & 天津 & 30 & & 江苏 & 3 \\
\hline & 河北 & 10 & & 浙江 & 17 \\
\hline & 山西 & 24 & & 安徽 & 5 \\
\hline & 内蒙古 & 9 & & 福建 & 19 \\
\hline \multirow{3}{*}{ 东北地区 } & 辽宁 & 15 & & 江西 & 13 \\
\hline & 吉林 & 14 & & 山东 & 2 \\
\hline & 黑龙江 & 1 & & 广东 & 16 \\
\hline \multirow{5}{*}{ 西北地区 } & 陕西 & 20 & \multirow[t]{2}{*}{ 华南地区 } & 广西 & 18 \\
\hline & 甘肃 & 21 & & 海南 & 29 \\
\hline & 青海 & 26 & \multirow{6}{*}{ 西南地区 } & 重庆 & 22 \\
\hline & 宁夏 & 28 & & 四川 & 7 \\
\hline & 新疆 & 11 & & 贵州 & 23 \\
\hline \multirow{3}{*}{ 华中地区 } & 河南 & 4 & & 云南 & 12 \\
\hline & 湖北 & 8 & & 西藏 & 31 \\
\hline & 湖南 & 6 & & & \\
\hline
\end{tabular}

由表7的排名可以看出区域间和区域内的绿色农业发 展是不均衡的, 尤其是东北地区和华东地区最为突出。东 北地区除黑龙江排名第一以外, 其余两个地区均为中等发 展水平。华东地区是东部沿海地区, 经济水平较高, 地理 位置优越，但由于区域内各地区经济结构的不同，导致区 域内绿色农业发展差异化极大。也有区域内发展均衡的地 区，如华中地区、西北地区和华南地区等。中国各省市绿 色农业发展水平总体差异是由地区内的差异引起的, 如地 区的经济结构、地理位置、耕地面积、自然条件等多方面 因素。

\section{5. 绿色农业发展水平的聚类分析}

\section{1. 系统聚类分析}

为了进一步观察地区之间绿色农业发展水平的相似 性, 本文采用多元统计软件SPSS的系统聚类法, 对 2018 年中国 31 个省市绿色农业发展水平高低进行分类分析。

\section{2. 聚类分析结果}

依据文中所取的 19 个指标数据, 使用SPSS软件对原始 数据进行聚类分析, 分析结果见表 8 。

表8 聚类分析结果。

\begin{tabular}{|c|c|c|c|}
\hline \multicolumn{2}{|l|}{ 群集成员 } & \multicolumn{2}{|l|}{ 群集成员 } \\
\hline 案例 & 4群集 & 案例 & 4群集 \\
\hline 1: 北京 & 1 & 17:上海 & 1 \\
\hline 2:天津 & 1 & 18: 江苏 & 2 \\
\hline 3:河北 & 2 & 19:浙江 & 3 \\
\hline 4:山西 & 3 & 20: 安徽 & 2 \\
\hline 5: 内蒙古 & 2 & 21:福建 & 3 \\
\hline 6:辽宁 & 2 & 22:江西 & 3 \\
\hline 7:吉林 & 3 & 23:山东 & 4 \\
\hline 8:黑龙江 & 2 & 24:广东 & 3 \\
\hline 9:陕西 & 3 & 25:广西 & 3 \\
\hline 10: 甘肃 & 2 & 26 :海南 & 1 \\
\hline 11:青海 & 1 & 27:重庆 & 3 \\
\hline 12:宁夏 & 1 & 28:四川 & 2 \\
\hline 13:新疆 & 4 & 29:贵州 & 3 \\
\hline 14:河南 & 2 & 30:云南 & 2 \\
\hline 15 : 湖北 & 3 & 31:西藏 & 1 \\
\hline 16:湖南 & 2 & & \\
\hline
\end{tabular}

根据系统聚类分析结果可以看出, 我们把 31 个省市的 绿色农业发展水平分为四个类别, 我们将这四个类别分别 命名为: 绿色农业发展高水平地区、绿色农业发展较高水
平地区、绿色农业发展中等水平地区和绿色农业发展低水 平地区。 
第一类: 北京、天津、青海、宁夏、上海、海南、西 藏属于绿色农业发展低水平地区, 主要原因是农作物播种 面积少, 粮食产量不高, 自身农业发展水平较低。其中, 2018年北京市农作物播种面积只有103.8千公顷，是全国 最少, 上海和西藏农作物播种面积也只有 200 多千公顷。 另外, 西藏、青海和宁夏的绿色原料生产基地数和绿色食 品生产资料获证企业数均为零, 绿色农业产品品牌发展水 平落后。

第二类: 河北、内蒙古、辽宁、黑龙江、甘肃、河南、 湖南、江苏、安徽、四川、云南属于绿色农业发展较高水 平地区。这类地区的绿色农业资源利用水平较低, 其中, 这 11 个省市中有 7 个省市的农用薄膜使用量超过 10 万吨, 是全国使用量最多的7个省市。但这一类地区总体绿色农 业发展水平时较高的, 主要归功于农作物播种面积多, 粮 食产量多, 总体森林覆盖率高, 除了甘肃、湖南和云南三 个省以外，其余地区均为中国粮食主产区，2018年粮食产 量占中国粮食总产量的 $53 \%$, 自身农业经济发展水平高。

第三类: 山西、吉林、陕西、湖北、浙江、福建、江 西、广东、广西、重庆、贵州属于绿色农业发展中等水平 地区。化肥和农药施用效率低是制约吉林、陕西、湖北、 广东和广西绿色农业发展的共同因素。国家农业示范区少、 绿色食品原材料生产基地数少进一步限制该区域内绿色 农业发展。

第四类: 新疆和山东是绿色农业发展高水平地区。新 疆和山东绿色农业发展水平高主要在于化肥、农药和薄膜 的高效率使用, 另外, 山东和新疆在绿色农业产品品牌方 面也表现较好, 山东的国家现代农业示范区有788个, 全 国最多, 新疆绿色食品原料标准化生产基地数在全国排名 第三。新疆和山东绿色农业发展水平较高主要归功于资源 利用效率高, 农作物播种面积多, “三品一标”产品数量多, 绿色产品品牌发展水平高。

\section{6. 结论分析与建议}

\section{1. 结论分析}

通过建立绿色农业指标体系, 运用组合评价法对中国31 个省市2018年绿色农业发展水平进行测量和评价。根据计算 结果得出以下结论: (1)组合评价法对中国绿色农业指标权重 赋值均具有合理性, 比单一的赋权法更具有客观性、综合性、 代表性, 可以全面的对中国31个省市绿色农业水平做出综合 评价。(2)运用客观赋权法（主成分分析法、因子分析法、摘 值法）计算出权重和排名, 再用组合评价法计算出中国 31 个 省市绿色农业发展水平的综合得分及综合排名。其中黑龙江、 山东、江苏、河南、安徽在全国排名前五, 较为落后的五个 地区分别是北京、宁夏、海南、天津和西藏。(3)中国绿色农 业发展水平具有明显的区域特征, 从中国七大经济区划分来 看, 华中地区整体发展均衡且发展水平较高。西北地区和华 南地区整体发展较为均衡, 但是整体绿色农业水平较低。东 北地区和华东地区两区域内部发展不均衡, 地区间差异化较 大。(4)中国绿色农业发展水平差异化是区域内引起的, 比如 区域内地区的农业经济基础、经济结构、地理位置等引起的。 (5)通过对中国 31 个省市绿色农业发展水平进行聚类分析, 结
果分为四个类别, 分别是绿色农业发展高水平地区、绿色农 业发展较高水平区域、绿色农业发展中等水平区域和绿色农 业发展低水平区域。(6)中国绿色农业发展水平的高低受农业 生产环境影响最大。

\section{2. 建议}

以上结论分析得出, 中国绿色农业发展还存在一些问 题, 从七大经济区的整体排名可以看出, 中国绿色农业虽 然存在区域集约化, 但是内部发展还不均衡, 存在差异化。 为了实现中国绿色农业高质量, 均衡发展, 提出以下建议: (1)绿色农业生产环境很重要, 要打造环保、高效、节约型 绿色农业产业链, 加强一二三产业融合发展, 建设高质量 绿色农业生产基地, 加快国家现代农业示范园的建立。(2) 各省政府应针对自身发展情况制定相关农业政策和规划, 制定绿色农业生产计划。控制农药、化肥、农用薄膜的使 用, 推广节水灌溉技术和绿色生产资料。同时借助自身资 源禀赋, 调整优化农产品结构, 打造特色绿色农产品, 加 快“三品一标”产品的认证, 生产安全、健康、绿色的农产 品, 形成品牌效应。(3)加快土地流转, 完善土地流转相关 政策，提高绿色农业生产集约化、规模化，使用高技术农 用机械, 提高绿色农业生产效率。(4)中国地区间绿色农业 发展水平不平衡, 区域内高水平地区可以和低水平地区协 同发展, 建立合作关系, 相互学习, 共同提高, 提升区域 内整体绿色农业发展水平。(5)绿色农业发展高水平地区, 可以借助区位优势, 紧紧抓住经济发达但绿色农业发展低 水平地区的消费市场, 输出更多绿色农产品, 满足消费者 个性化需求。(6)培育新型农民, 提高农民的综合素质，提 升广大农民的绿色农业生产意识。

\section{致谢}

本文是在张婷老师的耐心指导下完成, 老师和蔼可亲, 认真指导了我论文的框架和细节, 在写作过程中, 老师严 谨的语言表达和渊博的知识让我受益良多, 在此向她表示 由衰的感谢! 感谢!

同时向在百忙之中评审本文的各位老师表示衰心的

\section{参考文献}

[1] 刘连馥. 绿色农业初探. 北京: 中国财经经济出版社, 2005: $64 \sim 67$.

［2]＼cjkstart严立冬等.绿色农业导论.人民出版社，2008.

[3] 王保利,姚延婷.绿色农业产业集群评价指标体系及应用研 究——以陕西省渭北绿色果品产业集群为例 [J].中国农学 通报,2006(08):588-593.

[4] 崔元锋,严立冬,陆金铸, 屈志光. 我国绿色农业发展水平综合 评价体系研究[J].农业经济问题,2009,30(06):29-33. 
[5] 张正斌,王大生,徐萍.中国绿色农业指标体系建设指导原则 和构架[J].中国生态农业学报,2011,19(06):1461-1467。

[6] 卢秉福,孙一鸣,韩卫平.黑龙江省绿色农业可持续发展主要 影响因素分析[J].中国农学通报,2011,27(32):110-113.

[7] 赵海波. 黑龙江省绿色农业发展研究[D].中共黑龙江省委 党校,2020.

[8] 田云,张俊遂.中国绿色农业发展水平区域差异及成因研究 [J].农业现代化研究,2013,34(01):85-89。

[9] 陆壮丽,谭静.广西农业绿色化发展水平评价指标体系的构 建 $[\mathrm{J}]$.农业网络信息,2016(11):12-15.

[10] 奉梅.四川省绿色农业发展区域特征及评价[J].中国农业资 源与区划,2019,40(01):42-47.
[11] 郭显光.一种新的综合评价方法一组合评价法 [J].统计研 究,1995(05):56-59.

[12] 王倩. 中国省域绿色农业发展空间差异及影响因素研究[D]. 贵州大学,2019.

[13] 陈玮荣. 江西电网Z供电分公司综合绩效评价研究[D].东华 理工大学,2019.

[14] 陆添超,康凯.熵值法和层次分析法在权重确定中的应用 [J]. 电脑编程技巧与维护,2009(22):19-20+53.

[15] 郭显光. 熵值法及其在综合评价中的应用 [J]. 财贸研 究,1994(06):56-60. 